\title{
Is it intestinal tuberculosis again? Case report
}

\author{
Kristián Brat ${ }^{1}, Z^{\text {deněk Merta', Ivan Čundrle }}{ }^{2}$ \\ 'Department of Respiratory Diseases, Faculty of Medicine, Masaryk University and University Hospital Brno \\ ${ }^{2}$ Department of Anaesthesiology and Intensive Care, Faculty of Medicine, Masaryk University and St. Anne's University Hospi- \\ tal, Brno
}

\section{Summary}

This case report focuses on an immigrant admitted to the Department of Respiratory Diseases, University Hospital Brno due to suspicion of relapsing intestinal tuberculosis. The patient presented with fever, night sweat, weight loss, diarrhea, and a history of several tuberculosis attacks in the last few years. None of the examinations confirmed the presence of active tuberculosis but raised suspicion of hematological malignancy. Pancytopenia was present in the peripheral blood. However, bone marrow examination and flowcytometry excluded the presence of a hematological malignancy. The results pointed to the possibility of vitamin $B_{12}$ or folate deficiency that were both confirmed consequently by serum biochemical tests. Cobalamin and folate deficiency were caused by short bowel syndrome that developed after a major intestinal resection that the patient underwent in his past. Combined treatment including vitamins, pancreatic enzymes substitution, antidiarrhoics and spasmolytics was administered. The general health status of the patient improved rapidly with restitution of hematopoiesis, weight gain, and a decrease by $80 \%$ in daily number of stools. Clinical appearance of intestinal tuberculosis, short bowel syndrome and of cobalamin and folate deficiency as well as pathophysiology, diagnosis and treatment of these uncommon or even rare diseases are discussed in this case report.

Key words: intestinal tuberculosis - pancytopenia - short bowel syndrome - vitamin $B_{12}$ deficiency

\section{Je to znovu střevní tuberkulóza? Kazuistika}

\section{Souhrn}

Tato kazuistika popisuje př́pad imigranta, který byl přijat na Kliniku nemocí plicních a tuberkulózy ve Fakultní nemocnici Brno kvůli podezření na recidivu střevní tuberkulózy. U pacienta přetrvávaly horečky, noční pocení, úbytek váhy a průjem. V posledních letech prodělal několik atak tuberkulózy. Žádné z vyšetření však nepotvrdilo př́tomnost aktivní formy tuberkulózy, ale vzniklo podezření na hematologickou malignitu. $V$ periferní krvi byla zjištěna pancytopenie. Avšak vyšetření kostní dřeně a průtoková cytometrie vyloučily hematologickou malignitu. Výsledky ukázaly na potenciální deficienci vitaminu $B_{12}$ nebo folátu a obojí bylo následně potvrzeno sérovými biochemickými testy. Nedostatek kobalaminu a folátu byl způsoben syndromem krátkého střeva, který se vyvinul v důsledku rozsáhlé resekce střeva, kterou pacient v minulosti podstoupil. Byla zavedena kombinovaná terapie, která obsahovala vitamíny, substituci pankreatickými enzymy, antidiaroika a spazmolytika. S restitucí krvetvorby, váhovým př́růstkem a snížením denního počtu stolic o 80 \% se celkový zdravotní stav pacienta rychle zlepšil. Tato kazuistika se zaměřuje na klinické př́znaky střevní tuberkulózy, syndromu krátkého střeva a nedostatku kobalaminu a folátu, a dále na patofyziologii, diagnostiku a léčbu těchto neobvyklých, nebo dokonce vzácných onemocnění.

Klíčová slova: střevní tuberkulóza - pancytopenie - syndrom krátkého střeva - nedostatek vitaminu $\mathrm{B}_{12}$

\section{Case presentation}

A 42-year old man - an immigrant from Armenia was admitted to the Department of Respiratory Diseases, University Hospital Brno, for suspected relapse of tuberculosis (TB). The patient suffered from fever and night sweats of approximately eight weeks' duration. Furthermore, he complained of having lost $19 \mathrm{~kg}$ during the last 12 months, nausea, anorexia, weakness, dizziness and severe diarrhoea (up to 15 stools per day).
His history revealed:

1. pulmonary and intestinal TB in 1995 when the patient underwent resection of approximately 3.5 meters of the small intestine (treated in Armenia)

2. laryngeal TB in 2004 treated with anti-tuberculous drugs (standard regimen - Directly Observed Treatment-Short Course - DOTS), 2 months isoniazide (H), rifampin $(R)$, ethambutol $(E)$, pyrazinamide $(Z)$ and 4 months HR (treated in Armenia) 
3. pulmonary and intestinal TB in 2007 treated with anti-tuberculous drugs (ATD). The patient completed the initial 2 months HRZE regimen and consecutively discontinued to use the ATD treatment due to depression (treated in the Czech Republic)

4. depressive disorder treated by antidepressants

\section{Drug history}

Drug history showed regular use of clonazepam, mianserin, venlafaxine and sulpiride.

The patient was a smoker and an alcohol abuser; he completed an addiction treatment in 2006.

\section{Physical examination}

On physical examination, the patient had signs of anemia (pallor, dizziness, tachypnea), anxiety and depression, icterus, and diffuse abdominal pain. Auscultation showed normal breathing. Initial blood pressure was $130 / 70 \mathrm{~mm} \mathrm{Hg}$ and he had regular heart rate of 95 beats per minute. Hemoglobin saturation was $97 \%$, body temperature was $37.1{ }^{\circ} \mathrm{C}$ and respiratory rate was 14 per minute. BMI of the patient was 21.1 at the time of initial examination.

Initial laboratory results showed severe anemia (blood hemoglobin $54 \mathrm{~g} / \mathrm{l})$, leucopenia $\left(2.98 \times 10^{9} / \mathrm{l}\right)$, thrombocytopenia $\left(43.7 \times 10^{12} / \mathrm{l}\right)$, while biochemical tests showed elevation of lactatedehydrogenase $(60.03 \mu \mathrm{kat} / \mathrm{l})$ and increased bilirubin.

Early differential diagnosis was:

- recurrent pulmonary TB and gastrointestinal bleeding of unknown origin

- intestinal TB or

- hematological malignancy

Fig. 1. Chest X-ray taken ca 12 months prior to the patient admission to the Department of Respiratory Diseases, University Hospital Brno, showing posttuberculous fibrosis and numerous calcified nodular lesions in the upper lobes

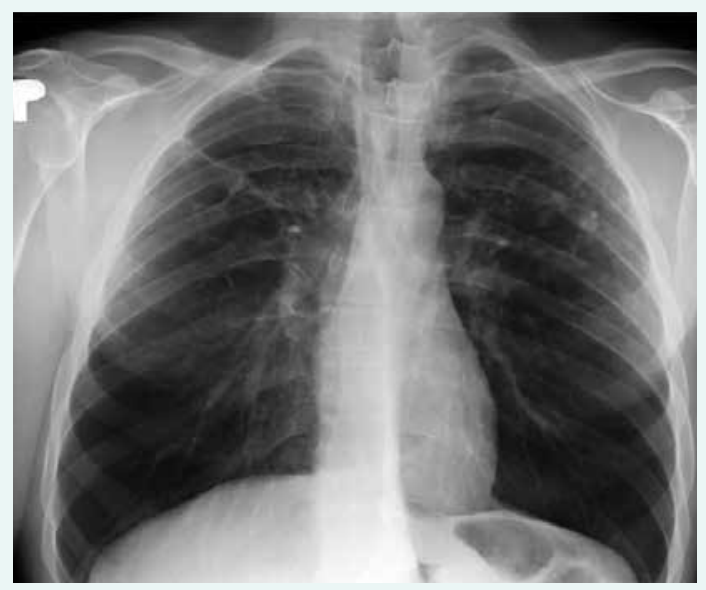

The chest X-ray was identical like than 1 year before, i.e. post-tuberculous fibrosis and calcified tuberculous nodules affecting both lungs (fig. 1 and fig. 2). No signs of recent pulmonary infiltrates were present. Gastrofibroscopy and colonoscopy were negative in the sense of bleeding or presence of a tumor. Repeated smear and stool samples were microscopy and MGIT negative, cultivation of stool was negative (Mycobacterium tuberculosis and opportunistic pathogens). Abdominal ultrasound showed gallbladder lithiasis.

\section{Working diagnosis}

After the above mentioned tests were completed, working diagnosis of hematological malignancy appeared to be most probable. For suspicion of leukemia or myelodysplastic syndrome, sternal puncture and cytoflowmetry were performed. However, these showed normal cell counts and excluded the presence of malignant cells in the peripheral blood and bone marrow. The patient was HIV negative. Bone marrow examination showed hypercellular marrow with trilinear hematopoiesis. Myeloid-to-erythroid ratio was decreased to $1: 1$ (normal is $3: 1$ ), megakaryocyte counts were reduced while megaloblastic erythropoiesis and hypersegmentation of neutrophilic granulocytes were dominant.

\section{Further biochemical tests}

Further biochemical tests showed extreme deficiency of cobalamin $\left(B_{12}\right)$ and folate $\left(B_{9}\right)$.

Since there were no signs of a malignancy, cobalamin and folate substitution treatment was administered after a consultation with a hematologist. Moreover, an-

\section{Fig. 2. Chest X-ray taken at patient admission} to the Department of Respiratory Diseases, University Hospital Brno, showing posttuberculous fibrotic changes and numerous calcified nodular lesions in the upper lobes - the finding is identical than 12 months ago (see fig. 1)

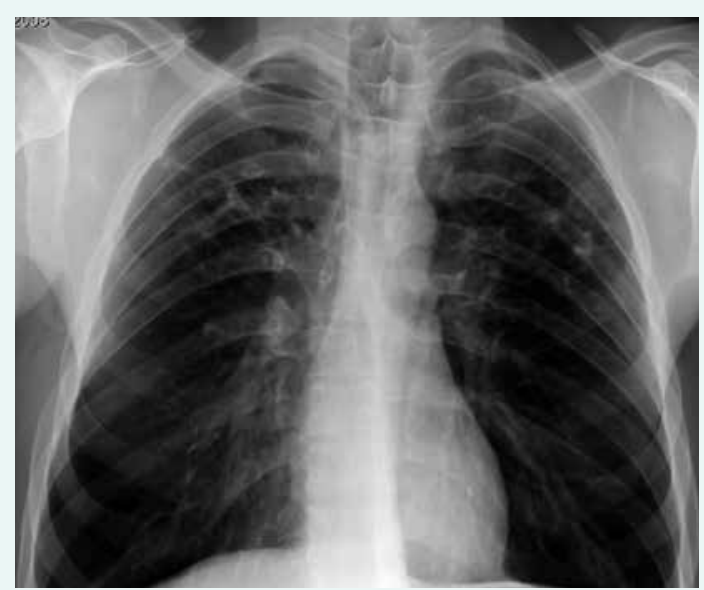


tidiarrhoic treatment (loperamide), probiotics, spasmolytics (drotaverine), hepatoprotective agents (silymarin) and substitution of vitamins $A, D, E, K$ and of pancreatic enzymes (pancreatinum) were administered. Tab. 1 shows the results of biochemical tests performed during the hospital stay with respect to timeline.

By the end of the first week of this combined treatment, reticulocyte crisis was observed. Reticulocyte counts in the peripheral blood exceeded $10 \%$ of red blood cells (RBC), peaking at $17 \%$ of RBC on day 12 of the hospital treatment. At the same point, restitution of white blood cell and thrombocyte counts to normal physiological values were observed. Blood hemoglobin concentration was increasing as well. The number of daily stools decreased from 15 to 3-5 and the patient gained $3 \mathrm{~kg}$ on weight. Cultivation of stool and smears was repeatedly negative. The patient was discharged with medication combined of antidiarrhoics, spasmolytics and substitution of pancreatic enzymes and vitamins $A, D, E, K$ and $B_{12}$. The results of selected hematological tests performed during the hospital stay are shown in tab. 2.

\section{Final diagnosis}

The final diagnosis per exclusionem was short bowel syndrome with an extreme multi-vitamin deficiency

\section{Tab. 1. Serum biochemical parameters during hospital stay. Abnormal values are in bold}

\begin{tabular}{|c|c|c|c|c|}
\hline hospital stay (day) & day 1 & day 10 & day 15 & day 19 \\
\hline \multicolumn{5}{|l|}{ parameter (reference values) } \\
\hline urea (1.7-8.3 mmol/l) & 7 & 6.1 & 7.8 & 10.4 \\
\hline creatinine $(62-115 \mu \mathrm{mol} / \mathrm{l})$ & 85 & 89 & 93 & 81 \\
\hline natrium (136-145 mmol/l) & 137 & 142 & 142 & 143 \\
\hline potassium $(3.5-5.1 \mathrm{mmol} / \mathrm{l})$ & 3.9 & 4.3 & 5.0 & 4.4 \\
\hline chloride (98-107 mmol/l) & 107 & 114 & 111 & 110 \\
\hline calcium (2.15-2.55 mmol/l) & 2.08 & 2.11 & 2.34 & $x$ \\
\hline magnesium $(0.65-1.05 \mathrm{mmol} / \mathrm{l})$ & 0.7 & $x$ & $x$ & $x$ \\
\hline bilirubin $(2-21 \mu \mathrm{mol} / \mathrm{l})$ & 35.4 & 29.6 & 23.5 & 17.1 \\
\hline ALT (0.17-0.85 $\mu \mathrm{kat} / \mathrm{l})$ & 0.78 & 0.36 & 0.27 & 0.21 \\
\hline AST $(0.17-0.85 \mu \mathrm{kat} / \mathrm{l})$ & 1.8 & 0.39 & 0.39 & 0.29 \\
\hline GGT (0.13-1.02 $\mu \mathrm{kat} / \mathrm{l})$ & 0.32 & 0.32 & 0.33 & 0.27 \\
\hline ALP (0.67-2.15 $\mu \mathrm{kat} / \mathrm{l})$ & 0.55 & 0.60 & 0.67 & 0.59 \\
\hline AMS (0-1.67 $\mu \mathrm{kat} / \mathrm{l})$ & 1.04 & 1.07 & $x$ & 1.02 \\
\hline lipase $(0.22-1 \mu \mathrm{kat} / \mathrm{l})$ & 0.55 & 0.50 & $x$ & $x$ \\
\hline LD (2.25-3.75 $\mu \mathrm{kat} / \mathrm{l})$ & 60.03 & 25.55 & $x$ & $x$ \\
\hline total protein $(64-83 \mathrm{~g} / \mathrm{l})$ & 72.3 & $x$ & $x$ & $x$ \\
\hline glucose $(3.1-5.6 \mathrm{mmol} / \mathrm{l})$ & 4.8 & $x$ & $x$ & $x$ \\
\hline CRP $(0-5 \mathrm{mg} / \mathrm{l})$ & $<1.0$ & $<1.0$ & $x$ & $<1.0$ \\
\hline transferine $(2-3.6 \mathrm{~g} / \mathrm{l})$ & 2.54 & $x$ & $x$ & $x$ \\
\hline ferritine $(30-400 \mu \mathrm{g} / \mathrm{l})$ & 369.5 & $x$ & $x$ & $x$ \\
\hline vitamine $B_{12}(145-637 \mathrm{pg} / \mathrm{ml})$ & 22 & $x$ & $x$ & $x$ \\
\hline folate $(7-39.7 \mathrm{ng} / \mathrm{ml})$ & $<1.0$ & $x$ & $x$ & $x$ \\
\hline $\mathrm{Fe}(10.6-28.3 \mu \mathrm{mol} / \mathrm{l})$ & 50.5 & $x$ & $x$ & $x$ \\
\hline $\mathrm{T}_{\text {Sat }}(0.21-0.4)$ & 0.79 & $x$ & $x$ & $x$ \\
\hline albumin (34-48 g/l) & 44.2 & $x$ & $x$ & 43.1 \\
\hline TSH (0.27-4.2 mU/l) & 5.56 & $x$ & $x$ & $x$ \\
\hline $\mathrm{fT}_{4}(12-22 \mathrm{pmol} / \mathrm{l})$ & 16.5 & $x$ & $x$ & $x$ \\
\hline CK (0.63-2.91 $\mu \mathrm{kat} / \mathrm{l})$ & 0.87 & $x$ & $\mathrm{X}$ & $x$ \\
\hline$\beta_{2}$-microglobulin $(0-2.4 \mathrm{mg} / \mathrm{l})$ & 2.76 & $x$ & $x$ & $x$ \\
\hline
\end{tabular}

ALP - Alkaline Phosphatase ALT - Alanine Aminotransferase AMS - Total Amylase AST - Aspartate Aminotransferase B $_{12}$ - Cobalamin (Vitamin B12) CK - Creatine Kinase CRP - C-reactive Protein Fe - Serum Iron fT4 - Free Thyroxine GGT - Gamma-glutamyl transferase LD - Lactate Dehydrogenase TSat - Transferrin Saturation TSH - Thyroid-stimulating Hormone $\mathbf{X}$ - parameter not measured 
resulting in severe pancytopenia and malnutrition. No signs of pulmonary or intestinal TB were observed.

\section{Discussion}

In this case report, severe pancytopenia was demonstrated in a patient suspected of having intestinal TB relaps. The initial symptoms and history of intestinal TB lead to the suspicion of intestinal TB relaps. However, TB was not confirmed and short bowel syndrome was diagnosed in this patient. In this presented patient, the most probable scenario was extensive resection of a large portion of the small intestine leading to the development of malabsorption, diarrhea and extreme vi$\operatorname{tamin} \mathrm{B}_{12}$ and $\mathrm{B}_{9}$ deficiency. This state resulted in pancytopenia with clinical presentation in the form of anemic syndrome and leucopenia. The clinically most relevant diseases with respect to differential diagnosis are discussed below.

\section{Tab. 1. Serum biochemical parameters during hospital stay. Abnormal values are in bold}

\begin{tabular}{|c|c|c|c|c|c|}
\hline hospital stay (day) & day 1 & day 3 & day 8 & day 12 & day 23 \\
\hline \multicolumn{6}{|l|}{ parameter (reference values) } \\
\hline WBC $\left(4-10 \times 10^{9} / \mathrm{I}\right)$ & 2.98 & 2.16 & 3.53 & 4.53 & 8.26 \\
\hline $\operatorname{RBC}\left(4-5.9 \times 10^{12} / \mathrm{I}\right)$ & 1.32 & 2.17 & 1.86 & 2.87 & 3.19 \\
\hline Hgb (130-176 g/l) & 54 & 79.9 & 68.9 & 101 & 103 \\
\hline Hct $(0.39-0.51)$ & 0.15 & 0.22 & 0.19 & 0.29 & 0.31 \\
\hline MCV (84-96 fl) & 111 & 99.6 & 102 & 102 & 96.7 \\
\hline MCH (28-34 pg) & 41 & 36.9 & 37 & 35.3 & 32.4 \\
\hline MCHC (320-370 g/l) & 368 & 370 & 363 & 345 & 335 \\
\hline RDW (10-15.2 \%) & 22.9 & 21.9 & 22.6 & 19.3 & 15.4 \\
\hline Plt $\left(150-350 \times 10^{9} / \mathrm{I}\right)$ & 43.7 & 36 & 32.8 & 166 & 212 \\
\hline Pct $(1.21-3.5 \mathrm{ml} / \mathrm{l})$ & 0.5 & 0.28 & 0.22 & 1.79 & 2.08 \\
\hline MPV (7.8-11 fl) & 11.4 & 7.82 & 6.73 & 10.7 & 9.8 \\
\hline PDW (15.5-17.1 \%) & 20.2 & 17.6 & 14.5 & 24.3 & 16.2 \\
\hline$\%$ Neu (50-70) & 30.7 & 30.5 & 21.3 & 36.7 & 73.1 \\
\hline$\%$ Lym (20-40) & 61.6 & 61.7 & 63.7 & 43.6 & 17.3 \\
\hline$\%$ Mono (2-12) & 5.75 & 4.11 & 9.94 & 14.2 & 7.33 \\
\hline$\% \operatorname{Eos}(0-5)$ & 1.35 & 2.97 & 4.89 & 3.43 & 2.21 \\
\hline$\%$ Bas $(0-1)$ & 0.68 & 0.69 & 0.13 & 2.10 & 0.06 \\
\hline Neu $\left(2-7 \times 10^{9} / \mathrm{I}\right)$ & 0.92 & 0.66 & 0.75 & 1.66 & 6.04 \\
\hline $\operatorname{Lym}\left(0.8-4 \times 10^{9} / \mathrm{I}\right)$ & 1.84 & 1.33 & 2.25 & 1.97 & 1.43 \\
\hline Mono $\left(0.08-1.2 \times 10^{9} / \mathrm{l}\right)$ & 0.17 & 0.09 & 0.35 & 0.64 & 0.61 \\
\hline Eos $\left(0-0.5 \times 10^{9} / \mathrm{I}\right)$ & 0.04 & 0.06 & 0.17 & 0.16 & 0.18 \\
\hline $\operatorname{Bas}\left(0.01-0.1 \times 10^{9} / \mathrm{l}\right)$ & 0.02 & 0.01 & 0 & 0.09 & 0 \\
\hline PTs (12-17) & 14.4 & $x$ & $x$ & $x$ & $x$ \\
\hline PTR (0.8-1.2) & 1.13 & $x$ & $x$ & $x$ & $\mathrm{x}$ \\
\hline aPTTs (28-42) & 34.8 & $x$ & $x$ & $x$ & $x$ \\
\hline aPTTR (0.8-1.2) & 0.99 & $x$ & $x$ & $x$ & $x$ \\
\hline $\mathrm{DD}(0-0.5 \mu \mathrm{g} / \mathrm{ml})$ & 1.62 & $x$ & $x$ & $x$ & $x$ \\
\hline \% AT III (80-120) & 71 & $x$ & $x$ & $x$ & $x$ \\
\hline$\%$ reticulocytes $(0.5-2.5)$ & $x$ & 0.94 & 3.41 & 17.5 & $x$ \\
\hline reticulocytes $\left(25-75 \times 10^{9} / \mathrm{I}\right)$ & $x$ & 20.4 & 63.6 & 501 & $x$ \\
\hline
\end{tabular}

\% AT III - Antithrombin III (\%) \% Bas - Basophils (\%) \% Eos - Eosinophils (\%) \% Lym - Lymphocytes (\%) \% Mono - Monocytes (\%) \% Neu - Neutrophils (\%) aPTTR - Activated Partial Thromboplastin Time (ratio) aPTTs - Activated Partial Thromboplastin Time (seconds) Bas - Absolute Basophil Count DD - D-dimer Eos - Absolute Eosinophil Count Hct - Hematocrite Hgb - Hemoglobin Lym - Absolute Lymphocyte Count MCH - Mean Cell Hemoglobin MCHC - Mean Cell Hemoglobin Concentration MCV - Mean Cell Volume Mono - Absolute Monocyte Count MPV - Mean Platelet Volume Neu - Absolute Neutrophil Count Pct - Plateletcrit PIt - Platelet count PDW - Platelet Distribution Width PTR - Prothrombin Time (ratio) PTs Prothrombin Time (seconds) RBC - Red Blood Cells RDW - Red Cell Distribution Width WBC - White Blood Cells X - parameter not measured 


\section{Gastrointestinal tuberculosis}

TB is an infectious disease caused by Mycobacterium tuberculosis complex. The prevalence of TB is high; about one third of the world population has been infected with Mycobacterium tuberculosis [1]. According to the WHO 2015 data, 10.4 million of new TB cases and 1.8 million TB deaths were reported worldwide [1]. TB primarily affects lungs; however it may disseminate and affect practically any other organ system.

According to the results of several epidemiological studies, extrapulmonary TB (EPTB) accounts for 4 to $48 \%$ of all TB cases with most frequently reported percentage being around $20 \%$ [2]. The wide variation in numbers of reported cases of EPTB is a consequence of different approaches in definition of EPTB. Some authors consider every case of non-bronchopulmonary TB as EPTB while others consider TB pleurisy as part of pulmonary TB [2]. Above that, major differences in EPTB incidence exist between countries and geographical regions [2].

Apart from the most abundant forms of EPTB (TB of lymph nodes and pleural TB), one of the most frequent extrapulmonary TB presentations is abdominal TB [2]. With the increasing prevalence of HIV, the incidence of abdominal TB is expected to rise. Most common forms of abdominal TB include peritoneal TB (wet type with ascites, dry type with adhesions and fibrotic type with omental thickening and loculated ascites) [3], TB of solid visceral organs, tuberculous lymphadenopathy and gastrointestinal TB [4]. Of the gastrointestinal TB forms, ileocaecal TB is most frequent with signs of ulcerations, fibrosis, and thickening and lamination of the bowel wall [3]. Oesophageal, gastric, colonic and rectal TB are less frequent forms of the disease [3].

According to latest epidemiological data, intestinal TB is an uncommon disease in the Western countries [5]. However, the incidence rates significantly differ for indigenous and immigrant subpopulations [5]. Previous reports estimated that abdominal TB may account for $5.8 \%$ [6] to $11 \%$ [7] of extrapulmonary manifestations of the disease or $5 \%$ of all reported TB cases [7]. In the Czech Republic, intestinal TB is a rare disease [8,9]. Overall 518 new cases of TB were reported in the Czech Republic in 2015 (incidence rate: 4.9/100.000), of these 67 cases were EPTB (12.9\%) [10]. The portion of immigrants was $21.2 \%$ of total TB cases [10]. In 2014, 3 cases of abdominal tuberculosis were reported (further not specified) [9], exact data for the year 2015 are not at our disposal.

There are multiple possible routes of gastrointestinal system infection by Mycobacterium tuberculosis complex. First is the ingestion of mycobacteria. Primary intestinal TB develops if mycobacteria are ingested with infected food/milk. Secondary intestinal TB develops if sputum containing mycobacteria is ingested (approximately $25 \%$ of patients with abdominal TB have also pulmonary TB) [11]. After ingestion, epitheloid tubercles are formed in the lymphoid tissue of the submucosa
[4]. After a few weeks tubercles may start to necrotize, leading to ulcerations and spreading of the disease into deeper tissues, adjacent lymph nodes, peritoneum or portal vein/hepatic arteries, which may lead to dissemination of the TB into solid organs like liver, spleen or pancreas [12]. Second route of infection is hematogenous, when Mycobacteria spread to the gastrointestinal system from different affected organs in the body (lungs, kidneys, lymph nodes, etc.) [4]. Third route of infection is via lymphatic channels from infected lymph nodes. The last fourth route of infections is contagious spread from infected adjacent organs (muscles abscess, adnexa, tuberculous spondylitis) [4].

Diagnosis of a gastrointestinal TB may be difficult since signs and symptoms of the disease are nonspecific. This may result in a late diagnosis and significant morbidity and mortality [13]. The diagnosis of abdominal TB is usually made by a combination of cultivation, radiological and histopathological studies [4]. In a study from Pakistan, poverty, concomitant pulmonary TB and family history of TB were the most frequent factors associated with the presence of abdominal TB in a cohort of 233 patients [14]. In two smaller studies from high income countries, abdominal pain, weight loss and diarrhea were the most common clinical manifestations of the disease $[15,16]$. Usual way of final diagnosis was histology [16] or positive cultivation [15]. Computed tomography, ultrasound and magnetic resonance imaging are methods of choice for solid organ lesions, lymphadenopathy and peritoneal TB. Colonoscopy or barium studies seem to be more useful for mucosal TB lesions [17]. Caseous necrosis in granulomas is the histological hallmark of TB [4]. Other laboratory findings include anemia, increased erythrocyte sedimentation rate and hypoalbuminemia. Tuberculous ascitic fluid is characterized by protein content more than $30 \mathrm{~g} / \mathrm{l}$, by total cell count $150-4000 / \mu \mathrm{l}$, by predominance of lymphocytes [3] and by increased levels of adenosine deaminase [18] and interferon- $\gamma$ [19]. The yield of ascitic fluid culture or smear is rather low [4]. The role of interferon- $\gamma$ release assays is yet unknown [6]. A combined diagnostic approach including a gastroenterologist, radiologist, pathologist and infectious disease specialist was underscored by Weng et al, 2015. In the differential diagnosis, the most important disease to exclude is Crohn's disease [6].

Treatment options include standard 6-month regimen ATD treatment (DOTS) and/or surgical therapy (if necessary). Current recommendations for the treatment of bronchopulmonary TB and EPTB are summarized in the American Thoracic Society guidelines for TB treatment (published 2016) [20].

\section{Short bowel syndrome}

Short bowel syndrome is characterized by inability to absorb the required minimum amount of macronutrients and/or water and electrolytes due to functional or anatomical loss of small intestine to less than $200 \mathrm{~cm}$ 
[21]. It usually follows surgical removal of large portions of small intestine and it usually does not occur if functional small intestine is longer than $200 \mathrm{~cm}$ [21]. Short bowel syndrome may also develop in patients with functional loss of small intestine, e.g. in cases of enteral fistulas bypassing the sections of the small intestine responsible for absorption of specific nutrients (e.g. enterostomia, entero-entero anastomosis etc). Meanwhile, intestinal failure is a state characterized as a "reduction of gut function below the minimum necessary for the absorption of macronutrients and/or water and electrolytes, such that intravenous supplementation is required to maintain health and/or growth" [22]. These two conditions are not synonymous but are closely linked together - the presence of short bowel syndrome is a common risk factor for developing intestinal failure.

Major symptoms of short bowel syndrome include abdominal pain, diarrhea, dehydration, malnutrition, weight loss and fatigue. Furthermore, associated lack of vitamins ( $A, D, E, K, B_{9}, B_{12}$ ) and minerals (calcium, iron, magnesium) may result in anemia, coagulopathy and other symptoms related to the specific nutrient deficiency [21]. Treatment includes substitution of depleted micronutrients and macronutrients using enteral supplements [21], while patients with intestinal failure require parenteral nutrition [21].

\section{Severe vitamin $\mathrm{B}_{12}$ and folate deficiency presenting as pancytopenia}

Vitamin $B_{12}$ and $B_{9}$ are biological substances important for DNA synthesis [23]. $B_{12}$ deficiency may develop in strict vegetarians (vegans), in patients with atrophic gastritis, chronic Helicobacter pylori infection, pernicious anemia (in our patient, antiparietal cell antibody test was negative), Diphyllobothrium latum intestinal infection or in those using $\mathrm{H} 2$ antagonists, omeprazole, colchicine or several other drugs in chronic medication [23]. Chronic $B_{12}$ and $B_{9}$ malabsorption may result in extreme vitamin deficiency and lead to the development of pancytopenia, neurological and gastrointestinal symptoms (retrospectively, neurological symptoms including an episode of convulsions have been identified in our patient's history - 3 months before the hospitalization at the Department of Respiratory Diseases), depression but also to increased susceptibility to $M y$ cobacterium tuberculosis infection [23]. Hematological examination usually reveals megaloblastic anemia, decrease in peripheral reticulocyte count, leucopenia, neutropenia with the presence of hypersegmented neutrophils and thrombocytopenia. Bone marrow usually shows hypercellular marrow with a reduced myeloid-to-erythroid ratio $(1: 1)$, presence of megaloblastic changes and signs of ineffective erythropoiesis [23]. Other signs, including the presence of Howell-Jolly bodies and Cabot rings in RBC, hypergranulated and hypersegmented polymorphonuclear cells and hypersegmentation in megakaryocytes may also be identified [23].
Treatment of vitamin $B_{12}$ and $B_{9}$ deficiency is based on substitution of the substances (either enteral or parenteral way). In severe vitamin $B_{12}$ deficiency, recommended substitution dosage is daily $1 \mathrm{mg}$ of cobalamin intramuscularly for one week, followed by $1 \mathrm{mg}$ weekly for four weeks and by $1 \mathrm{mg}$ monthly for the lifetime [23]. Folate deficiency should be treated by oral supplements where possible.

\section{Conclusion}

In this case report, we have demonstrated the need for a complex multidisciplinary approach in the diagnosis and treatment of rare diseases. This case report discusses diagnosis and treatment of intestinal tuberculosis, short bowel syndrome and pancytopenia caused by extreme cobalamin and folate deficiency.

\section{References}

1. WHO. Tuberculosis. Dostupné z WWW: <http://www.who.int/mediacentre/factsheets/fs104/en/>. [2017 Feb 11].

2. Kulchavenya E. Extrapulmonary tuberculosis: are statistical reports accurate? Ther Adv Infect Dis 2014; 2(2): 61-70. Dostupné z DOI: <http://dx.doi.org/10.1177/2049936114528173>.

3. Sharma MP, Bhatia V. Abdominal tuberculosis. Indian J Med Res 2004; 120(4): 305-315.

4. Debi U, Ravisankar V, Prasad KK et al. Abdominal tuberculosis of the gastrointestinal tract: Revisited. World J Gastroenterol 2014; 20(40): 14831-14840. Dostupné z DOI: <http://dx.doi.org/10.3748/wjg. v20.i40.14831>.

5. Caputo D, Alloni R, Garberini A et al. Experience with two cases of intestinal tuberculosis: utility of the QuantiFERON-TB Gold test for diagnosis. Surg Infect (Larchmt) 2008; 9(3): 407-410. Dostupné z DOI: <http://dx.doi.org/10.1089/sur.2007.006>.

6. Weng MT, Wei SC, Lin CC et al. Seminar Report From the 2014 Taiwan Society of Inflammatory Bowel Disease (TSIBD) Spring Forum (May 24th, 2014): Crohn's Disease Versus Intestinal Tuberculosis Infection. Intest Res 2015; 13(1): 6-10. Dostupné z DOI: <http://dx.doi. org/10.5217/ir.2015.13.1.6>.

7. Kapoor VK. Abdominal tuberculosis. Postgrad Med J 1998; 74(874): 459-467.

8. Kolek V. Tuberkulóza. In: Kolek $V$, Kašák $V$, Vašáková $M$ et al (eds). Pneumologie. 2nd ed. Maxdorf: Praha 2014: 225-243. ISBN 978-80-7345-387-9.

9. Ústav zdravotnických informací a statistiky ČR. Tuberculosis and respiratory diseases 2014. Dostupné z WWW: http://uzis.cz/publikace/ tuberkuloza-respiracni-nemoci-2014. [2017 Mar 7]

10. Wallenfels J. Epidemiological situation of tuberculosis in the Czech Republic in 2015. Stud Pneumol Phthiseol 2016; 76(5): 187-188.

11. Horvath KD, Whelan RL. Intestinal tuberculosis: return of an old disease. Am J Gastroenterol 1998; 93(5): 692-696.

12. Akhan $O$, Pringot J. Imaging of abdominal tuberculosis. Eur Radiol 2002; 12(2): 312-323.

13. Mukewar S, Mukewar S, Ravi R et al. Colon tuberculosis: endoscopic features and prospective endoscopic follow-up after anti-tuberculosis treatment. Clin Transl Gastroenterol 2012; 3: e24. Dostupné z DOI: <http://dx.doi.org/10.1038/ctg.2012.19>.

14. Saaiq M, Shah SA, Zubair M. Abdominal tuberculosis: epidemiologic profile and management experience of 233 cases. J Pak Med Assoc 2012; 62(7): 704-707.

15. Mamo JP, Brij SO, Enoch DA. Abdominal tuberculosis: a retrospective review of cases presenting to a UK district hospital. QJM 2013; 106(4): 347-354. Dostupné z DOI: <http://dx.doi.org/10.1093/qjmed/ hct003>. 
16. Gill P, Coatsworth NR, Gundara JS et al. Tuberculosis: experience in a low endemic area Australian tertiary hospital. World J Surg 2013; 37(5): 984-990. Dostupné z DOI: <http://dx.doi.org/10.1007/ s00268-013-1935-7>.

17. Marshall JB. Tuberculosis of the gastrointestinal tract and peritoneum. Am J Gastroenterol 1993; 88(7): 989-999.

18. Bhargava DK, Gupta M, Nijhawan $S$ et al. Adenosine deaminase (ADA) in peritoneal tuberculosis: diagnostic value in ascitic fluid and serum. Tubercle 1990; 71(2): 121-126.

19. Sathar MA, Simjee AE, Coovadia YM et al. Ascitic fluid gamma interferon concentrations and adenosine deaminase activity in tuberculous peritonitis. Gut 1995; 36(3): 419-421.

20. Nahid P, Dorman SE, Alipanah $\mathrm{N}$ et al. Official American Thoracic Society/Centers for Disease Control and Prevention/Infectious Diseases Society of America Clinical Practice Guidelines: Treatment of Drug-Susceptible Tuberculosis. Clin Infect Dis 2016; 63(7): e147-e195. Dostupné z DOI: <http://dx.doi.org/10.1093/cid/ciw376>.

21. Pironi L. Definitions of intestinal failure and the short bowel syndrome. Best Pract Res Clin Gastroenterol 2016; 30(2): 173-185. Dostupné z DOI: <http://dx.doi.org/10.1016/j.bpg.2016.02.011>.
22. Pironi L, Arends J, Baxter J et al. [Home Artificial Nutrition \& Chronic Intestinal Failure.; Acute Intestinal Failure Special Interest Groups of ESPEN]. ESPEN endorsed recommendations. Definition and classification of intestinal failure in adults. Clin Nutr 2015; 34(2): 171-180. Dostupné z DOI: <http://dx.doi.org/10.1016/j.clnu.2014.08.017>.

23. Briani C, Dalla Torre C, Citton V et al. Cobalamin deficiency: clinical picture and radiological findings. Nutrients 2013; 5(11): 4521-4539. Dostupné z DOI: <http://dx.doi.org/10.3390/nu5114521>.

\section{Kristián Brat, MD}

\section{$\triangle$ kristian.brat@seznam.cz}

Department of Respiratory Diseases, University Hospital Brno www.fnbrno.cz

Received 16. 3. 2017

Accepted 25. 5. 2017 